\title{
The effect of starch and starch-bioactive glass composite microparticles on the adhesion and expression of the osteoblastic phenotype of a bone cell line
}

\author{
Gabriela A. Silva ${ }^{\mathrm{a}, \mathrm{b}, *}$, Olga P. Coutinho ${ }^{\mathrm{c}}$, Paul Ducheyne ${ }^{\mathrm{d}}$, Irving M. Shapiro ${ }^{\mathrm{e}}$, Rui L. Reis ${ }^{\mathrm{a}, \mathrm{b}}$ \\ a3B's Research Group - Biomaterials, Biodegradables and Biomimetics-University of Minho, Campus de Gualtar, 4710057 Braga, Portugal \\ ${ }^{\mathrm{b}}$ Department of Polymer Engineering, University of Minho, Campus de Azurém, 4800058 Guimarães, Portugal \\ ${ }^{\mathrm{c}}$ Department of Biology, Center of Biology, University of Minho, Campus de Gualtar, 4710057 Braga, Portugal \\ ${ }^{\mathrm{d}}$ Center for Bioactive Materials and Tissue Engineering, University of Pennsylvania, Philadelphia, PA 19104, USA \\ ${ }^{\mathrm{e}}$ Department of Orthopaedic Surgery, Thomas Jefferson University, Philadelphia, PA 19107, USA
}

Received 28 May 2006; accepted 6 July 2006

Available online 28 July 2006

\begin{abstract}
There is a clear need for the development of microparticles that can be used simultaneously as carriers of stem/progenitor cells and as release systems for bioactive agents, such as growth factors or differentiation agents. In addition, when thinking on bone-tissueengineering applications, it would be very useful if these microparticles are biodegradable and could be made to be bioactive. Microparticles with all those characteristics could be cultured together with adherent cells in appropriate bioreactors to form in vitro constructs that can then be used in tissue-engineering therapies.

In this work, we have characterized the response of MC3T3-E1 pre-osteoblast cells to starch-based microparticles. We evaluated the adhesion, proliferation, expression of osteoblastic markers and mineralization of cells cultured at their surface. The results clearly show that MC3T3-E1 pre-osteoblast cells adhere to the surface of both polymeric and composite starch-based microparticles and express the typical osteoblastic marker genes. Furthermore, the cells were found to mineralize the extracellular matrix (ECM) during the culture period.

The obtained results indicate that starch-based microparticles, known already to be biodegradable, bioactive and able to be used as carriers for controlled release applications, can simultaneously be used as carriers for cells. Consequently, they can be used as templates for forming hybrid constructs aiming to be applied in bone-tissue-engineering applications.
\end{abstract}

(C) 2006 Elsevier Ltd. All rights reserved.

Keywords: Starch; Bioactive glass; Microspheres; Osteogenesis; Cell culture

\section{Introduction}

To try to regenerate bone has been a major goal of tissue-engineering research. A promising approach combines the use of scaffold materials together with autologous site-specific cells. In this way, it may be possible to construct a hybrid material that can repair an osseous defect. For this strategy to be successful, materials need to

\footnotetext{
*Corresponding author. Department of Polymer Engineering, University of Minho, Campus de Azurém, 4800058 Guimarães, Portugal. Tel.: + 351253604781 ; fax: + 351253604492 .

E-mail address: gsilva@dep.uminho.pt (G.A. Silva).
}

be generated that exhibit adequate physical and chemical properties, and at the same time enhance cell adhesion, proliferation and differentiation. An ideal substrate for the synthesis of bone should be able to promote the expression of the osteoblastic phenotype as well as provide a template for bone deposition [1]. Furthermore, it is desirable for excellent scaffold materials to release bioactive molecules in a controlled fashion such that cell adhesion, proliferation and other cellular functions are enhanced.

Starch-based materials were shown to possess a wide range of properties that support their potential for biomedical applications. Coupled with their biodegradable 
nature [2,3], the ability to be processed by diverse methods [4-6] and into diverse shapes (Three-dimensional (3D) porous scaffolds, microparticles, bone cements) [7-11], render these materials very attractive to be used as scaffolds. Blends of starch with different synthetic polymers have been studied for several biomedical applications, such as bone scaffolds [12-17] and drug release applications [7,18]. 3D porous scaffolds based on starch-based materials have been shown to be biocompatible and to possess excellent in vivo behavior $[12,14,16,19]$.

In this work, we have focused on the production of starch-based microparticles, which are bioactive [20] and can release, in a sustained manner, molecules of biological interest [18]. However, to be used for biomedical purposes, their behavior regarding critical cellular functions such as adhesion, proliferation and maintenance of a defined phenotype needs to be well known. If osteoblast-like cells can adhere and grow at the surface of the starch-based microparticles these substrates could be used for: (i) nonload bearing applications or as part of a 3D-construct; (ii) cultivating anchorage-dependent cells in a dynamic bioreactor and (iii) encapsulating bioactive molecules in the microparticles and simultaneously growing cells at the surface of the microparticles that would release encapsulated growth factors to stimulate proliferation and differentiation of adherent cells. Cell proliferation and differentiation would occur, giving origin to a hybrid cellmaterial construct. After moving the construct to the in vivo location, the biodegradable nature of the microparticles would allow them to be replaced by newly formed tissue.

The aim of the present study was to evaluate the ability of starch-based biodegradable microparticles to support cell adhesion, viability and phenotypic expression of osteoblastic markers by MC3T3-E1 cells. In order to assess this, we have used cells of pre-osteogenic lineage and cultured them for periods up to 14 days at the surface of both polymer and composite starch-based microparticles.

\section{Materials and methods}

\subsection{Materials}

Starch-based polymer (SPLA, a blend comprised of $50 \mathrm{wt} \%$ corn starch and $50 \mathrm{wt} \%$ polylactic acid) and composite (SPLA/BG, comprised of SPLA and $30 \%$ Bioactive Glass $45 \mathrm{~S} 5$ granules, with a composition of $46.1 \% \mathrm{SiO}_{2}, 24.4 \% \mathrm{Na}_{2} \mathrm{O}, 26.9 \% \mathrm{CaO}, 2.6 \% \mathrm{P}_{2} \mathrm{O}_{5}, \mathrm{~mol} \%$ ) microparticles were produced as described in a previous work [20]. Particle sizes between 210 and $350 \mu \mathrm{m}$ were selected over smaller ones, due to the following reasons: compared with smaller sizes, they have larger surface area, which might allow the adhesion of higher number of cells per particle and yield bigger hybrid constructs.

The cell line used in this work-MC3T3-E1, subclone 4, derived from fetal mouse calvaria, was purchased from American Tissue Cell Collection (ATCC). The cells were cultured in DMEM medium supplemented with $10 \%$ FBS and $1 \%$ of antibiotics (penicillin - streptomycin) and cultivated in standard tissue culture conditions $\left(37^{\circ} \mathrm{C}, 5 \% \mathrm{CO}_{2}\right)$.

\subsection{Cell adhesion to the surface of starch-based microparticles}

The ability of MC3T3-E1 cells to adhere to the surface of starch-based microparticles was evaluated for up to $6 \mathrm{~h}$. To determine the adhesion efficiency, $1 \mu \mathrm{l}$ volume of microparticles was added to a suspension of $2 \times 10^{5}$ cells. The cells were allowed to adhere for $30 \mathrm{~min}, 1,2$ and $6 \mathrm{~h}$. After each time period, the microparticles were washed to make them free of non-adherent cells and transferred to a new vial. A volume of trypsin, enough to cover the microparticles, was added to detach the adherent cells, which was then neutralized by the addition of complete culture medium. Cells were then counted in a Neubauer chamber. Adhesion efficiency was determined as the percentage of adhered cells versus the total number of cells seeded. Data reports results from 3 independent experiments.

\subsection{Cell seeding on the surface of starch-based microparticles}

Before being used in any cell culture experiments, starch-based microparticles were sterilized with $70 \%$ ethanol, allowed to dry and then hydrated in DMEM culture medium prior to cell seeding. A volume of $10 \mu \mathrm{l}$ of microparticles was then added to a suspension of $5 \times 10^{5}$ MC3T3E1 cells. The microparticles and cells were mixed and centrifuged for $30 \mathrm{~s}$ at $100 \mathrm{rpm}$. After a maximum period of $12 \mathrm{~h}$, the microparticles with seeded cells were transferred to 6 -well plates containing $40 \mu \mathrm{m}$ pore size cell strainers (BD Falcon, Bedford, MA, USA). The cell strainers prevented particle loss during culture medium changes.

The cells were cultured for 14 days and evaluated for cell proliferation, enzyme activity, gene expression and an end-point assay for mineralization by Alizarin Red staining.

\subsection{MC3T3-E1 viability assessment using confocal laser microscopy}

Viability of MC3T3-E1 cells adhered to starch-based microparticles was assessed by confocal laser microscopy (Inverted Confocal Microscope, Olympus FloView, Melville, NY, USA). For this purpose was used a viability fluorescent dye-CellTracker Green CMFDA (Molecular Probes, Eugene, OR, USA). This dye diffuses through the cell membranes and once inside the cell, the CellTracker, containing a chloromethyl group that reacts with thiols, is transformed into a cell-impermeant fluorescent dye-thioether adduct. Only living cells have the ability to allow this reaction to occur, and this principle was used to determine the distribution and viability of cells adhered to the surface of starch-based microparticles.

The medium from the samples (SPLA and SPLA/BG microparticles with adhered cells) was aspirated and replaced by a 1:1000 dilution of CellTracker in serum-free DMEM. After $30 \mathrm{~min}$ the working solution was removed and replaced with complete culture medium. After a second 30 min incubation period, the samples were analyzed in a laser confocal microscope, with an excitation laser of $517 \mathrm{~nm}$. Images for SPLA and SPLA/BG samples were obtained by stacking of $20 \mu \mathrm{m}$ planar slices.

\subsection{MC3T3-E1 DNA quantification}

DNA content, as a means of evaluating proliferation, was measured using the PicoGreen dsDNA kit (Molecular Probes, USA). PicoGreen dsDNA reagent is an ultra sensitive fluorescent nucleic acid stain for quantitating double-stranded DNA (dsDNA) in solution. At each time point in culture, cell strainers were removed and the contents (particles with cells) washed with isotonic saline solution and centrifuged. A minimal volume of $0.1 \mathrm{~N} \mathrm{NaOH}$ was added to release DNA from the cells. An aliquot of the DNA suspension was added to $10 \times$ TE (Tris-EDTA) buffer, to which was then added the PicoGreen reagent (previously prepared in $10 \times$ TE buffer) in a 1:1 vol:vol, and fluorescence measured in a microplate reader at 485 and $535 \mathrm{~nm}$ excitation and emission wavelengths, respectively. Lambda DNA was used as standard. The data presents results of at least three independent experiments. 


\subsection{Evaluation of alkaline phosphatase activity}

Alkaline phosphatase was measured using the AttoPhos AP fluorescent Substrate System (Promega, Madison, WI, USA). AttoPhos Substrate (2'-[2-benzothiazoyl]-6'-hydroxybezothiazole phosphate [BBTP]) is cleaved by alkaline phosphatase to produce inorganic phosphate $\left(\mathrm{P}_{\mathrm{i}}\right)$ and the alcohol, 2'-[2-benzothiazoyl]-6'-hydroxybenzothiazole (BBT). This enzyme-catalysed conversion of the phosphate form of AttoPhos Substrate to BBT is accompanied by an enhancement in fluorescence. Samples (microparticles and adhered cells) were transferred to a $1.5 \mathrm{ml}$ tube, centrifuged at $14,000 \mathrm{rpm}$ for $1 \mathrm{~min}$, the supernatant (culture medium) was discarded and the pellet was suspended in $1 \mathrm{ml}$ of ice-cold $0.9 \% \mathrm{NaCl}$ solution in $3 \mathrm{~mm}$ Tris- $\mathrm{HCl}(\mathrm{pH} 7.4)$ and again centrifuged at $14,000 \mathrm{rpm}$ for $1 \mathrm{~min}$. The pellet was solublized in $500 \mu \mathrm{l}$ of a $0.9 \% \mathrm{NaCl}$ and $0.2 \%$ Triton X-100 solution. One hundred $\mu$ of cell suspension were added to $200 \mu \mathrm{l}$ of Attophos reagent, mixed for $15 \mathrm{~min}$, after which $100 \mu \mathrm{l}$ were loaded into each well of a 96-well plate and fluorescence was read at $430 \mathrm{~nm}$ excitation and $595 \mathrm{~nm}$ emission.

\subsection{RNA extraction}

Total RNA was extracted using the TRIzol reagent (Life Technologies, Gaithersburg, MD). In order to isolate the RNA, chloroform was added to the samples (microparticles with adherent cells), followed by precipitation with isopropyl alcohol.

Samples were transferred to a $1.5 \mathrm{ml}$ tube, centrifuged at $14,000 \mathrm{rpm}$ for $2 \mathrm{~min}$ and the supernatant was removed. Then, $1 \mathrm{ml}$ of TRIzol was added to the pellet, and samples were resuspended about 10 times to lyse the cells. Afterwards, $250 \mu \mathrm{l}$ of chloroform were added to the samples and the mixture was vortexed. The mixture was then centrifuged at $14,000 \mathrm{rpm}$ for 10 min, at $4{ }^{\circ} \mathrm{C}$. The top aqueous fraction was collected into a RNase free tube, to which 2 volumes of isopropanol were added. The solutions were mixed and again centrifuged at $14,000 \mathrm{rpm}$, for $30 \mathrm{~min}$ at $4{ }^{\circ} \mathrm{C}$. The supernatant was discarded and $1 \mathrm{ml}$ of ethanol was added to wash the pellet by centrifugation at $14,000 \mathrm{rpm}, 6 \mathrm{~min}$, at $4{ }^{\circ} \mathrm{C}$. The supernatant was discarded and the samples were air dried for approximately $10 \mathrm{~min}$. The RNA samples were then resuspended in $40 \mu$ of mili-Q sterile water. The concentration and purity of the RNA were measured in a UV spectrophotometer at $260 \mathrm{~nm}$ and by calculating the A260/A280 ratio, respectively. The integrity of the RNA was assayed by electrophoresis of the samples in a $1 \%$ agarose gel.

\subsection{RT-PCR analysis of osteoblastic markers}

RT-PCR was performed using a one step procedure. The method was optimized to an amount of $200 \mathrm{ng}$ of RNA. The PCR reaction components were added in the following order: water $\left(\mathrm{ddH}_{2} \mathrm{O}\right)$, Reaction Mix (Invitrogen, Carlsbad, CA, USA), primers, sample RNA and the enzyme, Platinum ${ }^{\circledR}$ Taq DNA polymerase (Invitrogen, Carlsbad, CA, USA). The samples were then run in a program with the following parameters: (i) $42^{\circ} \mathrm{C}$ for $1 \mathrm{~h}$, (ii) $94^{\circ} \mathrm{C}$ for $4 \mathrm{~min}$, (iii) $94^{\circ} \mathrm{C}$ for $1 \mathrm{~min}$, (iv) $55^{\circ} \mathrm{C}$ for $1 \mathrm{~min}$, (v) $72{ }^{\circ} \mathrm{C}$ for $1 \mathrm{~min}$ and (vi) $72^{\circ} \mathrm{C}$ for $10 \mathrm{~min}$. Steps (ii)-(iv) were the amplification step (34 cycles). GADPH, a housekeeping gene, was run as the control.

After completion of the PCR, the products were electrophoresed in a $1.5 \%$ agarose gel, together with a $100 \mathrm{bp}$ DNA Ladder (Promega, Madison, WI, USA) and visualized in a Kodak UV imager.

\subsection{Mineralization assay: Alizarin Red}

The Alizarin Red mineralization assay was performed using the method described by Bodine et al. [21], with modifications. Samples were washed with PBS, and subjected to a fixative $10 \% \mathrm{v} / \mathrm{v}$ solution of formaldehyde in PBS for $15 \mathrm{~min}$. After removal of fixative, samples were washed twice with excess water and covered with Alizarin Red (AR) solution, followed by gentle agitation in an orbital shaker for $20 \mathrm{~min}$. The AR solution was then removed and the samples washed four times with mili-Q water. The samples were observed in an optical microscope with a coupled SPOT camera.

\subsection{Alizarin Red staining extraction}

The protocol for extraction of the Alizarin Red staining was adapted from Gregory et al. [22]. Five hundred $\mu$ of acetic acid $(10 \% \mathrm{v} / \mathrm{v})$ were added to the stained samples, incubated for $30 \mathrm{~min}$ at room temperature with mild shaking. The monolayer was then scrapped off the plate, transferred to a $1.5 \mathrm{~mL}$ tube and vortexed for $30 \mathrm{~s}$. The slurry was overlaid with $300 \mu$ of mineral oil to prevent evaporation and heated at $80^{\circ} \mathrm{C}$ for $10 \mathrm{~min}$. Then the samples were centrifuged for $15 \mathrm{~min}$ at $14,000 \mathrm{rpm}$. Three hundred $\mu \mathrm{l}$ of the supernatant was transferred to a $1.5 \mathrm{~mL}$ tube and mixed with $100 \mu \mathrm{L}$ of a $10 \% \quad(\mathrm{v} / \mathrm{v})$ solution of ammonium hydroxide. One hundred $\mu \mathrm{L}$ aliquots were transferred to a 96-well plate and the absorbance read at $430 \mathrm{~nm}$. At least 3 independent experiments were performed, each one with triplicates.

\subsection{Statistical analysis}

Results are expressed as mean \pm standard deviation. Differences between experimental results were analyzed according to a Student $t$-test, with $p<0.05$ considered statistically significant.

\section{Results}

\subsection{Adhesion of MC3T3-E1 cells to starch-based microparticles}

The first hours of contact between cells and materials are critical, since it is well known that for anchorage dependent cells, adhesion to a substrate has to occur within few hours, otherwise the cells will lose their viability [23]. In addition to anchoring cells, adhesive interactions activate various intracellular signaling pathways that direct cell viability, proliferation, and differentiation [24-26].

Thus, to establish the ability of a biomaterial to serve as a substrate for cell culture, the adhesion efficiency of cells needs to be evaluated prior to the establishment of the long-term culture system.

In this work, we evaluated the adhesion of MC3T3-E1 cells to starch-based microparticles and Fig. 1 presents the results for SPLA and SPLA/BG compared to cell adhesion to tissue culture polystyrene (TCPS), so far considered the ideal material for cell adhesion.

As expected, cell adhesion to TCPS reached the highest value from all conditions (90\% of all seeded cells). Cell adhesion to SPLA polymer microparticles was about $40 \%$ of the total number of seeded cells; for composite microparticles, this value reached $60 \%$. Statistical analysis revealed significant differences between SPLA and TCPS $(p=0.0016), \quad$ SPLA/BG and TCPS $(p=0.0147)$ and between SPLA and SPLA/BG $(p=0.0158)$. The difference in adherence values probably reflects the variation in material properties, in terms of chemistry, surface charges, reactive groups and roughness.

We also evaluated the thiols status (which provides a mean of evaluating cell viability) of cells adhered to the surface of both polymer and composite microparticles 
using confocal laser microscopy after 1 and 2 days in culture.

Figs. 2A and D show the fluorescence of cells adhered to TCPS after 1 and 2 days, respectively. It is noticeable that they are spread over the surface, and this behavior is also observed at day 2 (Fig. 2D). The fluorescence of the cells is high, indicating that the cells are in a reduced thiol status and hence viable. Cells are clearly attached to both SPLA (Figs. 2B and E) and SPLA/BG (Figs. 2C and F) microparticles at day 1, although some of the cells present a round morphology and appear to be clumped together.

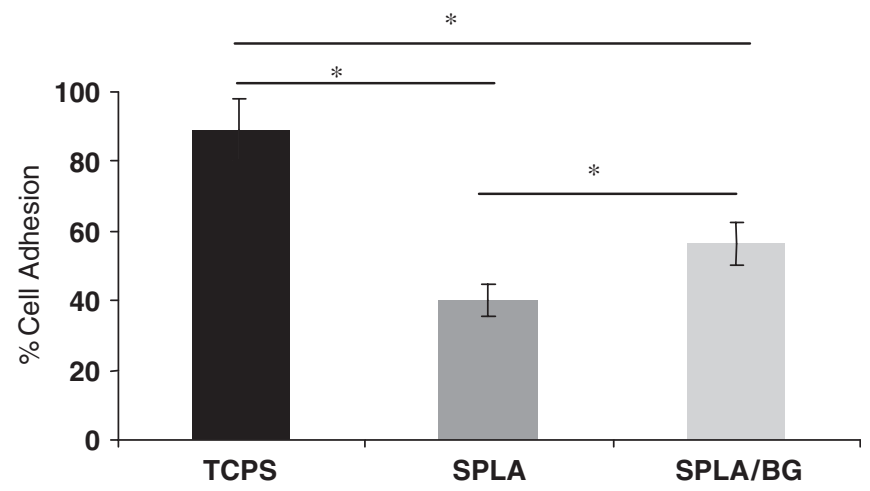

Fig. 1. MC3T3-E1 cell adhesion to tissue culture polystyrene (TCPS), SPLA polymeric and SPLA/BG composite microparticles after $6 \mathrm{~h}$ of adhesion. Cell adhesion was evaluated by removing adhered cells from the surface of the microparticles and counting in a hemocytometer. The $t$-test result revealed statistically significant differences between all conditions (TCPS vs. SPLA, $n=3, p=0.0016$; TCPS vs. SPLA/BG, $n=3$, $p=0.0147$; SPLA vs. SPLA/BG, $n=3, p=0.0158$ ).
However, at day 2 of culture, cells are well adhered to the microparticles (Figs. 2E and F), and completely cover the surface of some of the microparticles of the aggregate (Fig. 2F). Again this is a rather good result, not typical at all for biodegradable materials.

Another interesting result is the formation of $3 \mathrm{D}$ aggregates between microparticles and cells (Figs. 3A and B). These aggregates are maintained throughout the culture period. Although these systems do not present sufficient mechanical properties to be used per se in load bearing applications, this behavior is desirable in dynamic cell culture conditions, such as those using bioreactors. Preliminary results have shown that these aggregates can be placed and cultured in the NASA-approved HARV bioreactor for up to 3 weeks without disaggregating the constructs.

\subsection{MC3T3-E1 proliferation at the surface of starch-based microparticles}

Cell proliferation at the surface of polymer and composite microparticles was measured by determining the increase in DNA content up to 14 days (Fig. 4).

MC3T3-E1 cells were able to proliferate at the surface of both polymer and composite microparticles at similar rates until 7 days of culture. Cells on TCPS proliferated at a ratio of $6 \times 10^{5}$ cells/day. In contrast, the rates on SPLA and SPLA/BG were $1.2 \times 10^{5}$ cells/day and $9.1 \times 10^{4}$ cells/ day, respectively. These statistically significant differences might be explained based on the surface of the materials. Starch-based microparticles, being composed of a polymeric
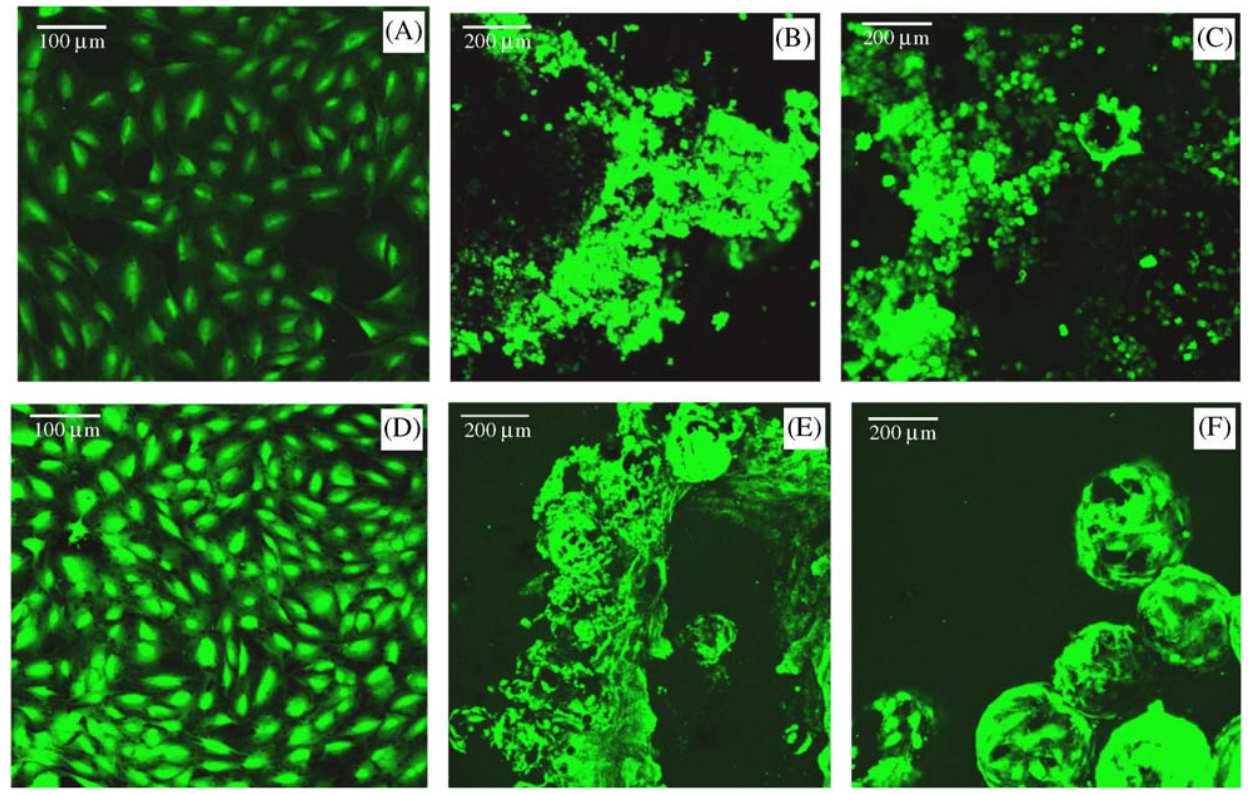

Fig. 2. Confocal laser microscopy of MC3T3-E1 cells stained with CellTracker green (A) and (D), TCPS; (B) and (E), SPLA; (C) and (F), SPLA/BG microparticles. (A), (B) and (C) show cells adhered to TCPS, SPLA and SPLA/BG microparticles after 1 day in culture, respectively. (D), (E) and (F) cells adhered to TCPS, SPLA and SPLA/BG microparticles after 2 days in culture, respectively. Cell viability and distribution in all conditions is evidenced by the green fluorescence. Images (B), (C), (E) and (F) were obtained by stacking of $20 \mu \mathrm{m}$ planar slices to build a three-dimensional image. Original magnification for (A) and (D): $80 \times$; for all others $40 \times$. 

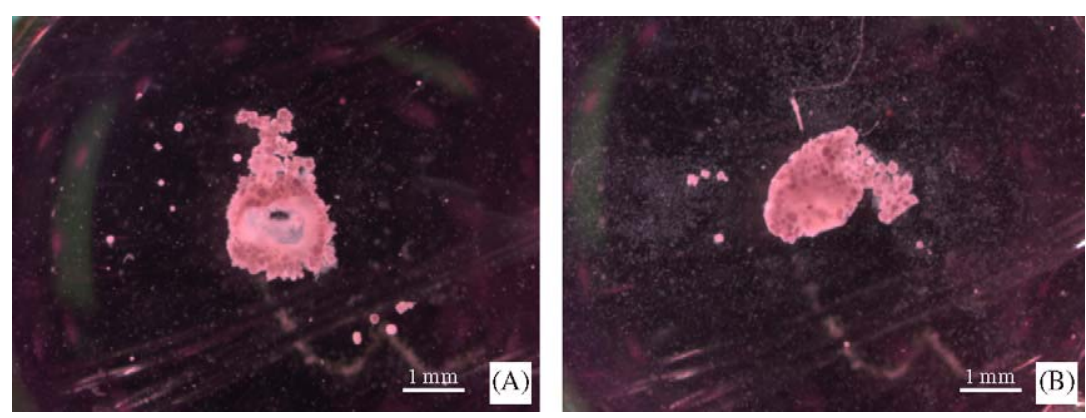

Fig. 3. Images of aggregates formed between cells and microparticles, similar to the ones in Fig. 2, at 14 days of culture. The images show 3D aggregates formed during the in vitro culture, and these aggregates were maintained throughout the whole culture period. (A) SPLA microparticles and (B) SPLA/BG microparticles. Original magnification $10 \times$.

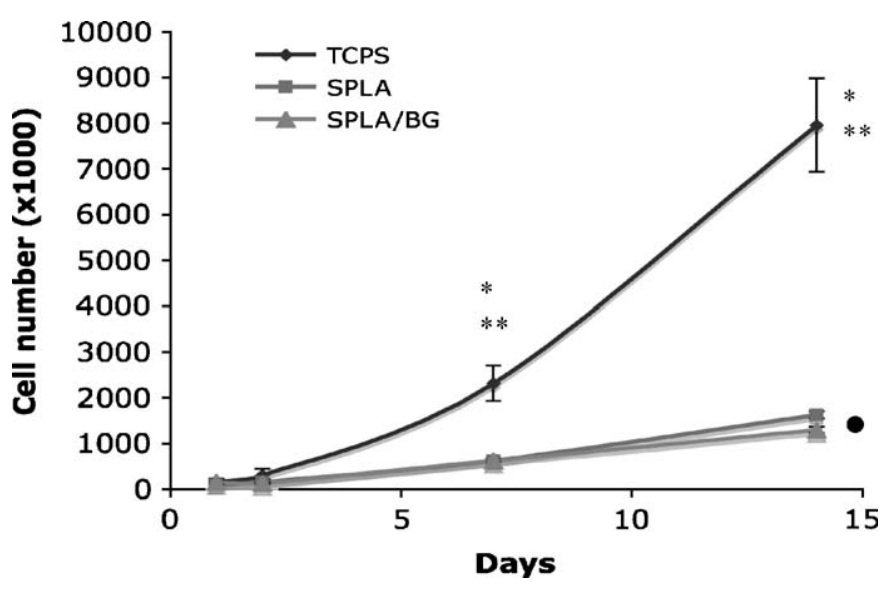

Fig. 4. MC3T3-E1 cell proliferation in TCPS, SPLA and SPLA/BG microparticles. Extrapolation from DNA to cell number was performed using a standard curve of DNA from known cell numbers. The proliferation of the cells is reduced for both polymer and composite microparticles when compared to TCPS. Nevertheless, cells are able to remain viable and proliferate at the surface of the carriers. Statistical analysis was performed through the $t$-test. ${ }^{*}$ and $* *$ indicate significant differences between TCPS and SPLA, SPLA/BG, respectively. Statistically significant differences between SPLA and SPLA/BG $(\bullet)$ found only for values at 14 days.

mixture of PLA and starch, have at their surface domains that are richer in PLA and others richer in starch. Therefore this creates some surface heterogeneity that might influence cell adhesion.

Differences between both starch-based particles are only observed after 7 days of culture, where cells at the surface of polymeric microparticles increase their number by approximately $10 \%$ more than cells cultured at the surface of composite microparticles, and this difference was found to be statistically significant ( $p=0.0068$ ).

\subsection{Alkaline phosphatase activity}

The data obtained from the measurement of alkaline phosphatase activity showed very low enzyme activity and no obvious differences among the materials and TCPS. MC3T3-E1 cells failed to express alkaline phosphatase, however, other works in Refs. [27-31] have shown these cells to be a good model of the osteoblastic lineage. Failing to express significant levels of alkaline phosphatase activity, nevertheless, does not impart the role of these cells as a model for the osteogenic pathway. Further results in this study show that these cells are in fact committed and able to maintain the osteoblastic lineage.

\subsection{Expression of osteoblastic marker genes}

Markers of the osteoblastic phenotype-osteopontin (OP), osteocalcin, collagen type I $\alpha$ and the transcription factor Runx-2, were analyzed by RT-PCR (Fig. 5).

On TCPS all the markers were expressed, although levels of OP and Runx-2 were low. On SPLA, the level of expression of Runx-2 and collagen type I $\alpha$ was similar to TCPS. In contrast to TCPS and SPLA, on SPLA/BG composite microparticles, there was a higher level of expression of all of the transcripts, which indicates that composite microparticles clearly enhance the expression of osteoblastic markers.

\subsection{Alizarin Red staining}

To examine the mineralization potential of MC3T3-E1 cells on TCPS, SPLA and SPLA/BG, we stained the cultures with Alizarin Red. Fig. 6 shows that both SPLA and SPLA/BG microparticles enhance mineralized nodule formation compared to cells cultured on a TCPS surface. Cells cultured on the standard tissue culture surface (TCPS) only showed Alizarin Red staining comparable to the one found in SPLA microparticles after 4 weeks of culture (data not shown).

When quantitatively analyzing, on a cell basis, the amount of deposited calcium (Fig. 7), cells cultured on standard conditions (TCPS) showed statistically significant lower levels when compared to polymeric (SPLA, $p=0.002$ ) and composite (SPLA/BG, $p<0.0001$ ). On SPLA/BG microparticles calcium was also found to have significantly higher values than those observed for SPLA samples $(p=0.0068)$. 


\section{Discussion}

Starch-based biodegradable microparticles were evaluated in this study for their ability to allow cell adhesion, proliferation and expression of the osteoblastic phenotype of cells cultured on their surface. One of the drawbacks of using biodegradable materials for many biomedical applications is the fact that their biodegradable nature challenges the adhesion of cells to their surface [32]. While for many materials low cell adhesion efficiency creates the need for surface modification [33], in this study, cell adhesion to the surface of non-surface modified starchbased microparticles reached values up to $60 \%$. Considering that the microparticles were not subjected to any kind of surface modification to enhance cell adhesion, cell adhesion values are likely due to the presence of high number of hydroxyl $(\mathrm{OH})$ groups at the surface of the microparticles due to the starch component of the material. For other starch-based materials, the adhesion of cells has been shown to be higher for materials with lower oxygen content [34], although hydroxyl groups/high ratio of oxygen to carbon have been shown to enhance cell adhesion [35,36]. Studies of the surface chemistry by X-ray Photoelectron Spectroscopy (XPS) could help

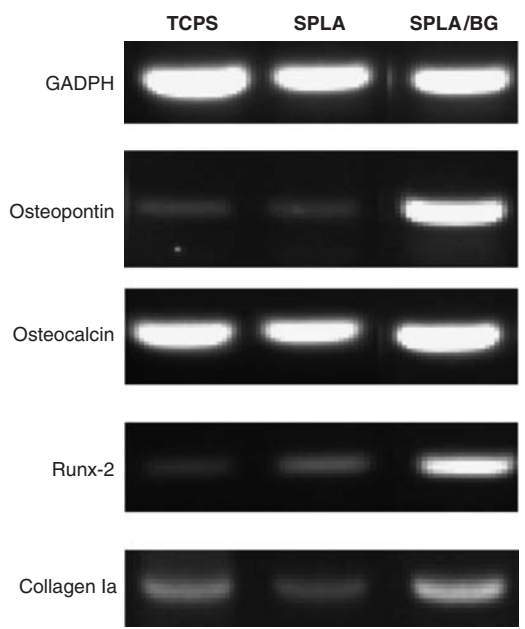

Fig. 5. RT-PCR analysis of osteoblastic genes expressed by MC3T3-E1 cells. Cells were cultured on TCPS, SPLA and SPLA/BG microparticles for 14 days, then evaluated by RT-PCR. Transcripts evaluated were osteopontin, osteocalcin, collagen type I $\alpha$ and Runx-2. GADPH, a housekeeping gene, was run as a loading control. elucidate this result. In addition, the presence of Bioactive Glass $45 \mathrm{~S} 5$ might also contribute to the differences in cell adhesion observed between polymer and composite microparticles. Bioactive Glass 45S5 has been extensively studied and it has shown, both in vitro and in vivo, adequate properties for osseous applications [37-44]. We have studied previously the production of composite SPLA-BG 45S5 microparticles [20], and observed that the surface morphology was not altered by the presence of the ceramic component. However, Bioactive Glass 45S5 might alter the surface chemistry of the microparticles and this can be the basis for the differential cell adhesion of MC3T3-E1 preosteoblastic cells to the surface of polymer and composite microparticles.

It was previously suggested [45] that surfaces that show good cell attachment at early time points do not necessarily promote cell proliferation or differentiation. In the present case, cell proliferation on the surface of both polymer and composite microparticles is significantly lower compared with proliferation values on TCPS. These rates can be due to (i) a heterogeneous surface, where domains richer in the starch component alternate with domains richer in the PLA component; (ii) degradation of the material, that causes removal of potential adhesion points for cells and

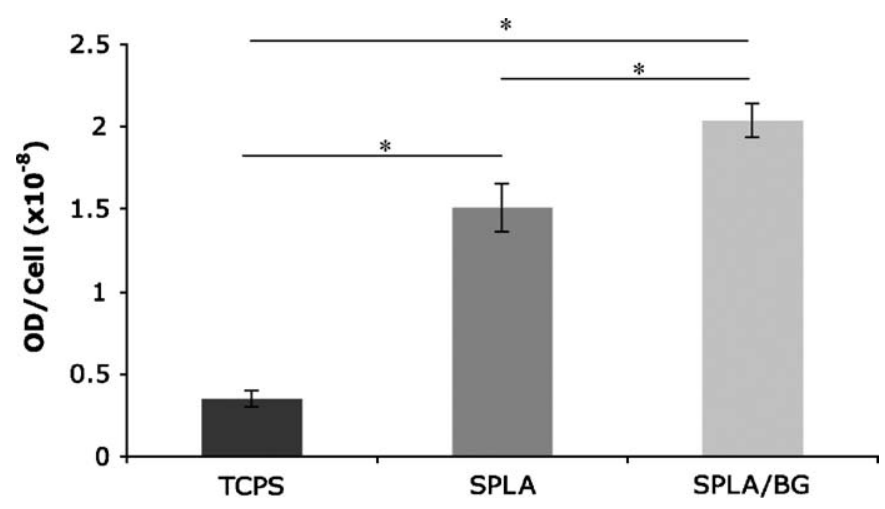

Fig. 7. Alizarin Red dye quantification for TCPS (control), SPLA and SPLA/BG microparticles. After staining the dye was extracted and quantified in a spectrophotometer. The OD values were normalized for the cell number. Statistically significant differences were found between all conditions (TCPS vs. SPLA, $p=0.002$; TCPS vs. SPLA/BG, $p<0.0001$; SPLA vs. SPLA/BG, $p=0.0068$, for $n=3$.
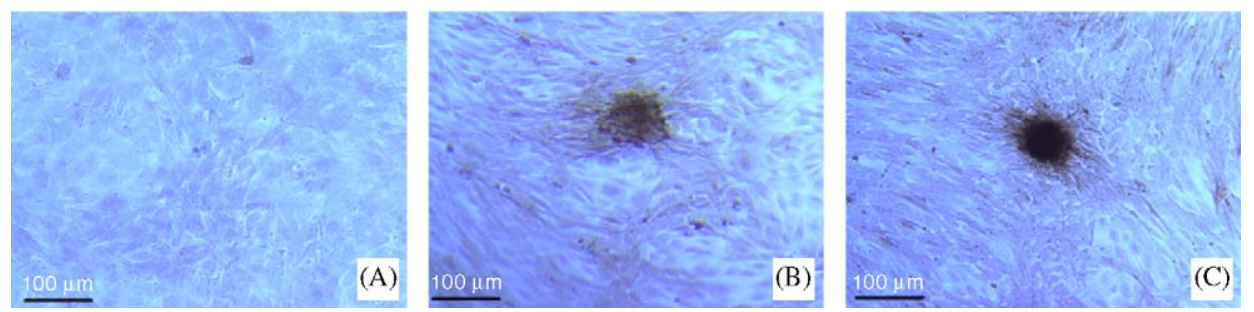

Fig. 6. Alizarin Red staining for TCPS (A), SPLA (B) and SPLA/BG (C) microparticles, evidencing the higher mineralization levels for both polymer and composite microparticles compared with TCPS. Original magnification $100 \times$. 
(iii) formation of 3D aggregates between microparticles and cells that may hinder the proliferation of cells in the inner areas of the aggregate. In this scenario, proliferation would be localized to the outer surface of the aggregate. A possible solution to overcome this drawback makes use of dynamic cell culture conditions, in which the circulation of nutrients and waste products removal is enhanced [46-48].

With these results, we would expect the osteoblastic phenotype of the cells to be affected. However, RT-PCR results show that cells are able to maintain their phenotype when cultured at the surface of the microparticles. Although only a residual amount of alkaline phosphatase was detected, gene expression constitutes a proof of the osteoblastic phenotype. Lineage allocation to osteoblasts has been shown to be controlled at the transcriptional level by Runx2, an osteoblast-specific transactivation factor $[49,50]$. In the present study Runx2 expression was observed for both polymer and composite microparticles, its expression being enhanced in composite SPLA/BG microparticles. The higher level of expression observed for cells cultured at the surface of composite microparticles was also observed for the other osteoblastic markers.

The differences in gene expression observed between polymer and composite materials are most likely due to the presence of Bioactive Glass 45S5. Other works [51-53] have shown that the ionic products of bioactive glass dissolution can stimulate genes concerned with osteoblastic metabolism and bone homeostasis. We have already shown before [20] that composite SPLA-BG microparticles are bioactive, and this bioactivity was shown in vitro by ionic dissolution followed by precipitation of calcium phosphate at the surface of the microparticles. In the present case, MC3T3E1 cells seem to be stimulated by composite microparticles to express higher level of gene transcripts that denote their osteoblastic nature, and we assume the presence of Bioactive Glass and the ionic dissolution phenomenon to be responsible for this result.

Well correlated with the results for gene expression are the results of the Alizarin Red staining, evidencing mineralization. For polymer and composite microparticles, mineralization was greatly enhanced when compared with the one for TCPS, both quantitatively and temporally. Cells in TCPS did attain similar levels of mineralization to those found for cells cultured on the surface of polymer microparticles, but with a 2-week delay.

In summary, although cell adhesion had lower values and proliferation rates are slower for polymer and composite microparticles when compared to control (TCPS), cell-specific functions were enhanced. Altogether, there was a more robust expression of the osteoblastic genes and an increase in critical mineralization activity. When SPLA and SPLA/BG are compared, the composite microparticles present a superior array of desirable features. These include bioactivity (as previously shown), higher values for cell adhesion as well as enhanced expression of osteoblastic markers and calcium deposition.

\section{Conclusions}

In a previous study we have proven, through the formation of a calcium-phosphate layer at their surface, the in vitro bioactivity of starch-based microparticles. This characteristic allows one to infer about the osteoconductive and osteoinductive behavior of these materials. Additionally, these materials were shown to be able to incorporate and release bioactive molecules, such as dexamethasone and growth factors. We now show yet another role of these microparticles, namely the enhancement of the expression of the osteoblastic phenotype by pre-osteoblastic cells cultured at their surface.

The data herein presented confirms that starch-based microparticles (both polymer and composite) are capable of supporting the in vitro growth and maturation of osteoblast-like cells. Differences between polymer and composite microparticles include higher cell adhesion values, mineral deposition and gene expression for the latter.

In addition to the previously described roles these systems can play, this study further confirms that these starch-based microparticles could be used in bone-tissueengineering strategies incorporating bioactivity, controlled release and cell support properties.

\section{Acknowledgements}

Mark Lee, Adam Zahm and Michael Bucaro are acknowledged for technical help. The Portuguese Foundation for Science and Technology (FCT) is acknowledged for a Ph.D. grant to G.A. Silva (SFRH/BD/4698/2001). This work was partially supported by FCT throught funds from the POCTI and/or FEDER programmes. The European Union-funded STREP Project Hippocrates (NNM-3-CT-2003-505758), the European NoE EXPERTISSUES (NMP3-CT-2004-500283) and NIH grant RO1 reference DE-13009, are also acknowledged.

\section{References}

[1] Kaufmann E, Ducheyne P, Shapiro IM. Evaluation of osteoblast response to porous bioactive glass (45S5) substrates by RT-PCR analysis. Tissue Eng 2000;6(1):19-28.

[2] Reis RL, Cunha AM. Characterization of two biodegradable polymers of potential application within the biomaterials field. J Mater Sci Mater Med 1995;6(12):786-92.

[3] Reis RL, Mendes SC, Cunha AM, Bevis MJ. Processing and in vitro degradation of starch/EVOH thermoplastic blends. Polym Int 1997;43(4):347-52.

[4] Gomes ME, Ribeiro AS, Malafaya PB, Reis RL, Cunha AM. A new approach based on injection moulding to produce biodegradable starch-based polymeric scaffolds: morphology, mechanical and degradation behaviour. Biomaterials 2001;22(9):883-9.

[5] Reis RL, Cunha AM, Bevis MJ. Using nonconventional processing to develop anisotropic and biodegradable composites of starch-based thermoplastics reinforced with bone-like ceramics. Med Plastic Biomater 1997;4:46-55. 
[6] Sousa RA, Oliveira AL, Reis RL, Cunha AM, Bevis MJ. Bicomposite sandwich moldings: processing, mechanical performance and bioactive behavior. J Mater Sci Mater Med 2003;14(5):385-97.

[7] Elvira C, Mano JF, San Roman J, Reis RL. Starch-based biodegradable hydrogels with potential biomedical applications as drug delivery systems. Biomaterials 2002;23(9):1955-66.

[8] Espigares I, Elvira C, Mano JF, Vazquez B, San Roman J, Reis RL. New partially degradable and bioactive acrylic bone cements based on starch blends and ceramic fillers. Biomaterials 2002;23(8):1883-95.

[9] Gomes ME, Godinho JS, Tchalamov D, Cunha AM, Reis RL. Alternative tissue engineering scaffolds based on starch: processing methodologies, morphology, degradation and mechanical properties. Mater Sci Eng C Biomimetic Supramol Syst 2002;20(1-2):19-26.

[10] Silva GA, Costa FJ, Pedro A, Coutinho OP, Reis RL. Soluble starch and composite starch-BG $45 \mathrm{~S}$ particles: synthesis, bioactivity and interaction with rat bone marrow cells. Mater Sci Eng C Biomimetic and Supramol Syst 2005;25(2):237-46.

[11] Boesel LF, Mano JF, Elvira C, Reis RL. Hydrogels and hydrophilic partially degradable bone cements based on biodegradable blends incorporating starch. In: Chiellini E, editor. Biodegradable polymers and plastics. Drodrecht: Kluwer Academic; 2003.

[12] Gomes ME, Reis RL, Cunha AM, Blitterswijk CA, de Bruijn JD. Cytocompatibility and response of osteoblastic-like cells to starchbased polymers: effect of several additives and processing conditions. Biomaterials 2001;22(13):1911-7.

[13] Gomes ME, Sikavitsas VI, Behravesh E, Reis RL, Mikos AG. Effect of flow perfusion on the osteogenic differentiation of bone marrow stromal cells cultured on starch-based three-dimensional scaffolds. J Biomed Mater Res Part A 2003;67A(1):87-95.

[14] Mendes SC, Bezemer J, Claase MB, Grijpma DW, Bellia G, DegliInnocenti $F$, et al. Evaluation of two biodegradable polymeric systems as substrates for bone tissue engineering. Tissue Eng 2003;9: S91-S101.

[15] Mendes SC, Reis RL, Bovell YP, Cunha AM, van Blitterswijk CA, de Bruijn JD. Biocompatibility testing of novel starch-based materials with potential application in orthopaedic surgery: a preliminary study. Biomaterials 2001;22(14):2057-64.

[16] Salgado AJ, Coutinho OP, Reis RL, Davies JE. In vivo response to starch based scaffolds designed for bone tissue engineering applications. J Biomed Mater Res 2005 in press.

[17] Salgado AJ, Gomes ME, Chou A, Coutinho OP, Reis RL, Hutmacher DW. Preliminary study on the adhesion and proliferation of human osteoblasts on starch-based scaffolds. Mater Sci Eng C-Biomimetic Supramol Syst 2002;20(1-2):27-33.

[18] Silva GA, Costa FJ, Neves NM, Coutinho OP, Dias ACP, Reis RL. Entrapment ability and release profile of corticosteroids from starchbased particles. J Biomed Mater Res 2005;73A(2):234-43.

[19] Marques AP, Reis RL, Hunt JA. The biocompatibility of novel starch-based polymers and composites: in vitro studies. Biomaterials 2002;23(6):1471-8.

[20] Silva GA, Costa FJ, Coutinho OP, Radin S, Ducheyne P, Reis RL. Synthesis and evaluation of novel bioactive starch/bioactive glass microparticles. J Biomed Mater Res 2004;70A:442-9.

[21] Bodine PV, Trailsmith M, Komm BS. Development and characterization of a conditionally transformed adult human osteoblastic cell line. J Bone Miner Res 1996;11(6):806-19.

[22] Gregory CA, Gunn WG, Peister A, Prockop DJ. An Alizarin Redbased assay of mineralization by adherent cells in culture: comparison with cetylpyridinium chloride extraction. Anal Biochem 2003;329(1): 77-84.

[23] Lee JW, Kim YH, Park KD, Jee KS, Shin JW, Hahn SB. Importance of integrin b1-mediated cell adhesion on biodegradable polymers under serum depletion in mesenchymal stem cells and chondrocytes. Biomaterials 2004;25:1901-9.

[24] Hynes RO. Integrins: bidirectional, allosteric signaling machines. Cell 2002;110:673-87.

[25] Giancotti FG, Ruoslathi E. Integrin signaling. Science 1999;285: 1028-32.
[26] Keselowsky BG, Collard DM, Garcia AJ. Surface chemistry modulates focal adhesion composition and signaling through changes in integrin binding. Biomaterials 2004;25:5947-54.

[27] Barbara A, Delannoy P, Denis BG, Marie PJ. Normal matrix mineralization induced by strontium ranelate in MC3T3-E1 osteogenic cells. Metabolism 2004;53(4):532-7.

[28] Quarles LD, Yohay DA, Lever LW, Caton R, Wenstrup RJ. Distinct proliferative and differentiated stages of murine MC3T3-E1 cells in culture: an in vitro model of osteoblast development. J Bone Miner Res 1992;7(6):683-962.

[29] St-Pierre JP, Gauthier M, Lefebvre LP, Tabrizian M. Threedimensional growth of differentiating MC3T3-E1 pre-osteoblasts on porous titanium scaffolds. Biomaterials 2005;26:7319-28.

[30] Sudo H, Kodama HA, Amagai Y, Yamamoto S, Kasai S. In vitro differentiation and calcification in a new clonal osteogenic cell line derived from newborn mouse calvaria. J Cell Biol 1983;96: 191-8.

[31] Tanaka SM, Sun HB, Roeder RK, Burr DB, Turner CH, Yokota H. Osteoblast responses one hour after load-induced fluid flow in a three-dimensional porous matrix. Calcif Tissue Int 2005;76:261-71.

[32] Verderio E, Coombes A, Jones RA, Li X, Heath D, Downes S, et al. Role of the cross-linking enzyma tissue transglutaminase in the biological recognition of synthetic biodegradable polymers. J Biomed Mater Res 2001;54:294-304.

[33] Lee SJ, Khang G, Lee YM, Lee HB. Interaction of human chondrocytes and NIH/3T3 fibroblasts on chloric acid-treated biodegradable polymer surfaces. J Biomater Sci Polym Ed 2002;13(2): 197-212.

[34] Marques AP, Reis RL. Hydroxyapatite reinforcement of different starch-based polymers affects osteoblast-like cells adhesion/spreading and proliferation. Mater Sci Eng C Biomimetic and Supramol Syst 2005;25:215-29.

[35] Hsu S-H, Tseng H-J. Polyurethane blended with polylactides for improved cell adhesion and reduced platelet activation. Artif Organs 1999;23(10):958-61.

[36] Feng B, Weng J, Yang BC, Qu SX, Zhang XD. Biomaterials 2003;24:4663-70.

[37] Hench LL, Xynos ID, Polak JM. Bioactive glasses for in situ tissue regeneration. J Biomater Sci Polym Ed 2004;15(4):543-62.

[38] Garcia AJ, Ducheyne P, Boettiger D. Effect of surface reaction stage on fibronectin-mediated adhesion of osteoblast-like cells to bioactive glass. J Biomed Mater Res 1998;40(1):48-56.

[39] ElGhannam A, Ducheyne P, Shapiro IM. Porous bioactive glass and hydroxyapatite ceramic affect bone cell function in vitro along different time lines. J Biomed Mater Res 1997;36(2):167-80.

[40] Nicoll SB, Radin S, Santos EM, Tuan RS, Ducheyne P. In vitro release kinetics of biologically active transforming growth factor-beta 1 from a novel porous glass carrier. Biomaterials 1997;18(12):853-9.

[41] ElGhannam A, Ducheyne P, Shapiro IM. Formation of surface reaction products on bioactive glass and their effects on the expression of the osteoblastic phenotype and the deposition of mineralized extracellular matrix. Biomaterials 1997;18(4):295-303.

[42] Schepers E, Declercq M, Ducheyne P. Histological and histomorphometrical analysis of bioactive glass and fiber reinforced bioactive glass dental root implants. J Oral Rehab 1988;15(5):473-87.

[43] Hattar S, Asselin A, Greenspan D, Oboeuf M, Berdal A, Sautier J-M. Potential of biomimetic surfaces to promote in vitro osteoblast-like cell differentiation. Biomaterials 2005;26:839-48.

[44] Gan JC, Ducheyne P, Vresilovic E, Shapiro IM. Bioactive glass serves as a substrate for maintenance of phenotype of nucleus pulposus cells of the intervertebral disc. J Biomed Mater Res 2000;51(4):596-604.

[45] Meyer U, Szulczewski DH, Moller K, Heide H, Jones DB. Cell Mater 1993;3:129.

[46] Freed LE, Vunjaknovakovic G, Langer R. Cultivation of cellpolymer cartilage implants in bioreactors. J Cell Biochem 1993;51(3): 257-64.

[47] Qiu Q, Ducheyne P, Gao H, Ayyaswamy P. Formation and differentiation of three-dimensional rat marrow stromal cell culture 
on microcarriers in a rotating-wall vessel. Tissue Eng 1998;4(1): 19-34.

[48] Sodian R, Lemke T, Fritsche C, Hoerstrup SP, Fu P, Potapov EV, et al. Tissue-engineering bioreactors: a new combined cell-seeding and perfusion system for vascular tissue engineering. Tissue Eng 2002;8(5):863-70.

[49] Viereck V, Siggelkow H, Tauber S, Raddatz D, Schutze N, Hufner M. Differential regulation of Cbfa1/Runx2 and osteocalcin gene expression by vitamin-D3, dexamethasone, and local growth factors in primary human osteoblasts. J Cell Biochem 2002;86: $348-56$.

[50] Merriman HL, van Wijnen HJ, Hiebert SW, Bidwell JP, Fey E, Lian $\mathrm{JB}$, et al. The tissue-specific nuclear matrix protein, NMP-2, is a member of the AML/CBF/PEBP2/Runt domain trancriptional factor family: Interactions with the osteocalcin gene promotor. Biochemistry $1995 ; 34: 13125-32$.

[51] Xynos ID, Edgar AJ, Buttery LDK, Hench LL, Polak JM. Ionic products of bioactive glass dissolution increase proliferation of human osteoblasts and induce insulin-like growth factor II mRNA expression and protein synthesis. Biochem Biophys Res Commun 2000;276:461-5.

[52] Xynos ID, Edgar AJ, Buttery LDK, Hench LL, Polak JM. Gene expression profiling of human osteoblasts following treatment with the ionic products of Bioglass 45S5 dissolution. J Biomed Mater Res 2001;55(2):151-7.

[53] Valerio P, Pereira MM, Goes AM, Leite MF. The effect of ionic products from bioactive glass dissolution on osteoblast proliferation and collagen production. Biomaterials 2004;25:2941-8. 